\title{
Heliodoros or the Fate of a Christian Councilman of Perinthos During the Great Persecution
}

\author{
Mehmet ALKAN* - Johannes NOLLÉ ${ }^{* *}$
}

In memory of Sencer Şahin

In 2012, a white marble sarcophagus was found in Gemlik, the ancient city of Kios, during sewerage works in Eskipazar Street, which traverses the city's Eşref Dinçer district. ${ }^{1}$ Its lid was broken into three pieces. Later the sarcophagus and the pieces of its smashed lid were transported to the garden of Gemlik Municipality.

A horizontal rectangular tabula with an inscription of eleven lines has been carved on one of the long sides of the sarcophagus. The opposite side of the chest is decorated with reliefs of three garlands attached at either end to a pair of bull heads-bukephala, ${ }^{2}$ evenly distributed over the long side-and to ram's heads at each corner (Fig. 4-6). Bunches of grapes are suspended from the middle of each garland, and two ribbons hang from each of the festoons. Knotted woolen cords hang vertically from the heads of the sacrificial animals. ${ }^{3}$ The decoration of the rear side of the sarcophagus indicates that it can be classified in the well known and common garland sarcophagi group. ${ }^{4}$

One of the narrow sides was also decorated with a garland between two panels, but the objects were only crudely hewn out and left incomplete. So, the bunch of grapes appears only as a heart-shaped object hanging downwards from the garland, and a rosette or patera above was left simply as a round boss (Fig. 7-8). The other side of the chest has a second tabula (Fig. 9-10), but this remained uninscribed. Obviously, the sarcophagus was intended to be used not only for the burial of Heliodoros, mentioned in the tabula on the front-side, but also for further interments.

The lid of the sarcophagus is roof-shaped and all of its corners were decorated with acroteria. One of the pediments is embellished with a patera or a rosette in relief (Fig. 8).

A vaulted burial chamber was unearthed close to where the sarcophagus was found (Fig. 11-15). ${ }^{5}$

* Yrd. Doç. Dr. Mehmet Alkan, Karamanoğlu Mehmetbey Üniversitesi, Edebiyat Fakültesi, Arkeoloji Bölümü, Yunus Emre Yerleşkesi, 70100 Karaman (mehmetalkan@kmu.edu.tr).

** Prof. Dr. Johannes Nollé, Kommission für Alte Geschichte und Epigraphik des Deutschen Archäologischen Instituts, Amalienstraße 73b, 80799 München (nolle@gmx.de).

${ }^{1}$ For the permission to publish this inscription we sincerely thank Prof. Dr. N. Eda Akyürek Şahin, who conducts the research project in the museums of Bursa, Eskişehir and Bilecik. We are also very grateful to the former director of Bursa Museum, Enver Sağır, who informed us about the sarcophagus and the burial chamber as well as to the assistant director, Koncagül Hançer.

${ }^{2}$ Cf. Börker 1975.

${ }^{3}$ For these sacrificial cords, called $\sigma \tau \varepsilon \dot{\varepsilon} \mu \alpha \tau \alpha$, cf. Gebauer 2002, 186-189.

${ }^{4}$ For the garland sarcophagi cf. Koch - Sichtermann 1982, 499-500. For details of semi-finished garland sarcophagi cf. Asgari 1977; Koch - Sichtermann 1982, 484-497.

${ }^{5}$ The burial chamber, which was partly destroyed during an earthquake, measures $1.63 \mathrm{~m}$ in height and $1.58 \mathrm{~m}$ in width. It was built from rubble stones; inside, the walls were covered with square shaped terracota plates measuring $0.33 \mathrm{~m} \times 0.33 \mathrm{~m}$ and being $0.04 \mathrm{~m}$ thick. By sieving the earth, with which the burial chamber 
This may suggest that other tombs were built in this area, so that a new necropolis may be added to the other ones already recorded in and around Kios. ${ }^{6}$

Measurements of the chest: length $2.10 \mathrm{~m}$, width $0.75 \mathrm{~m}$, height $0.83 \mathrm{~m}$, thickness of the sarcophagus' walls: $0.16 \mathrm{~m}$. Measurements of the lid : length $2.27 \mathrm{~m}$, width $1.07 \mathrm{~m}$, height $33.5 \mathrm{~m}$.

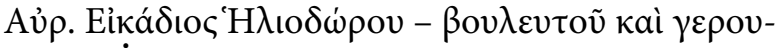

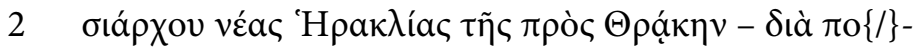

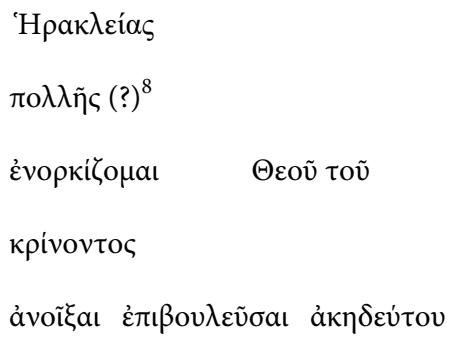

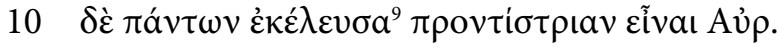

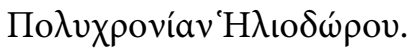

In this inscription, Alpha's horizontal bar is apex-shaped. Sigma has nearly the shape of a square bracket. Ypsilon sometimes has a horizontal line just below the angular upper part, sometimes not. Omega has a rather unusual form: Its main body consists of of an ellipse whose bottom part is cut off; inside of it we encounter an ypsilon-like small sign, that seems to represent the ends of the trimmed ellipse which in many inscriptions were very often turned inwards. There are occasional ligatures: $\mathrm{v} .5 \tau \varepsilon, 8 \mu \eta, 10 \nu \varepsilon, 11 v \varepsilon$. The writing of this inscription is uneven and irregular.

was filled, some pieces of cruse and dishes (figs. 17-18), numerous iron nails (19), two oxidised coins (Fig. 20) and a piece of a fitting (Fig. 21) were found in the tomb.

${ }^{6}$ IKios, s. 11-13; Sağır - Uzunoğlu - Hançer 2011, 32-34.

${ }^{7}$ The stonemason tried to chisel a lambda in the end of line 2, but had to accept that there was not enough space for this letter. That is why he started at the beginning of line 3 again with a lambda, but since it was very uncommon and bewildering for him to begin a line with two lambdas, he forgot the second one and engraved an alpha next to the lambda. Having finished this, he realised his mistake and carved another lambda. We can be sure that he corrected all these mistakes when he coloured the letters of the inscription in red. However, after the loss of colour, the faulty chiseling became visible again.

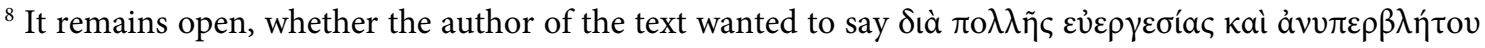

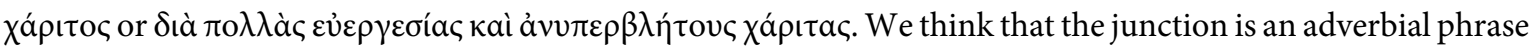

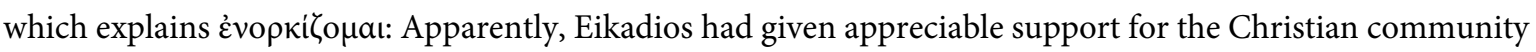
of Kios and had shown all his kindness to it. Therefore, in return he asks for their support in protecting his father's tomb.

${ }^{9}$ It seems that the stonecutter had forgotten to carve the lambda and later squeezed it between the two epsilon. 
I, Aurelios Eikadios, son of Heliodoros-who was a councilman and the head of the Gerusia of Nea Herakleia near the province of Thrace-due to many benefactions and unsurpassed pleasantness, also implore the servants of God-who will judge the living and the dead-that no other will open (the sarcophagus) and that no one will undertake attacks against my (up to now) unburied father Heliodoros, as he made himself a servant of the god, after he had come here (to Kios), so that he shall have this sarcophagus in return for all his troubles. I ordered that Aurelia Polychronia, the daughter of Heliodorus, should be the guardian of all these regulations.

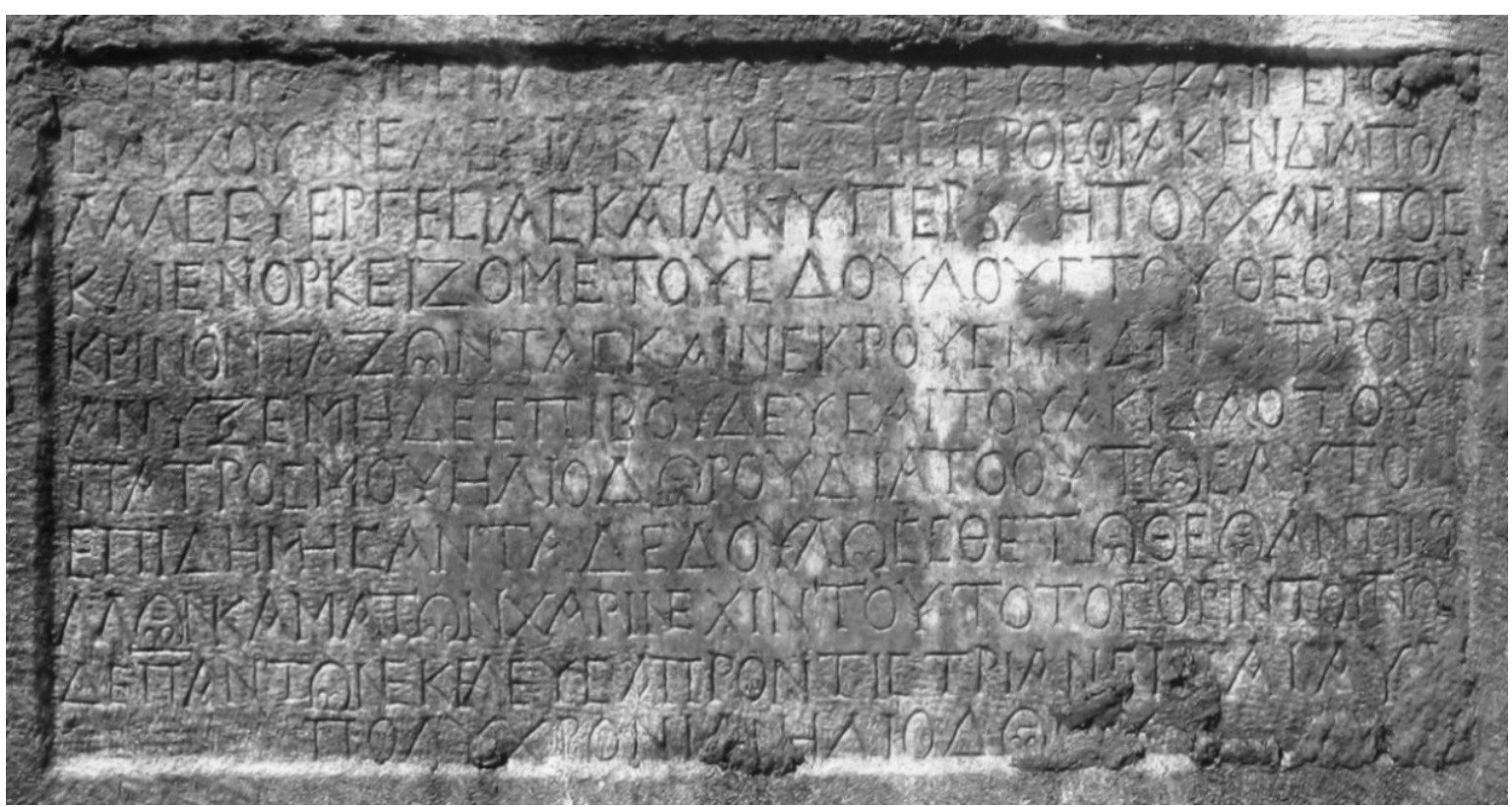

Fig. 1) The Inscription

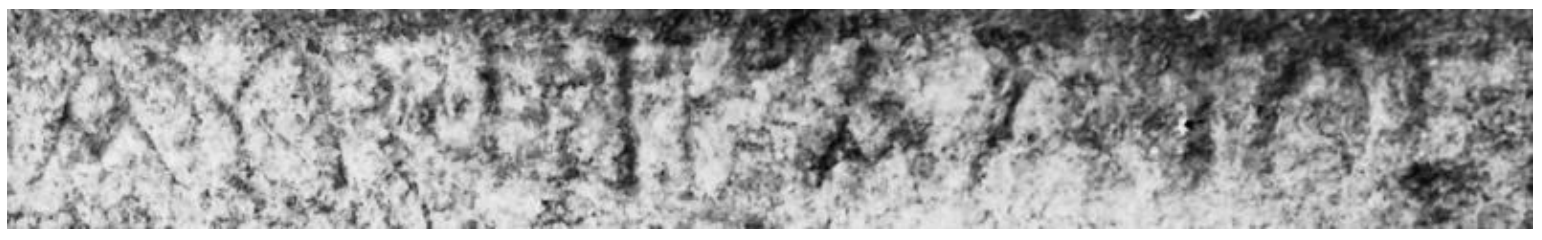

Fig. 2) The first two words of line 1.

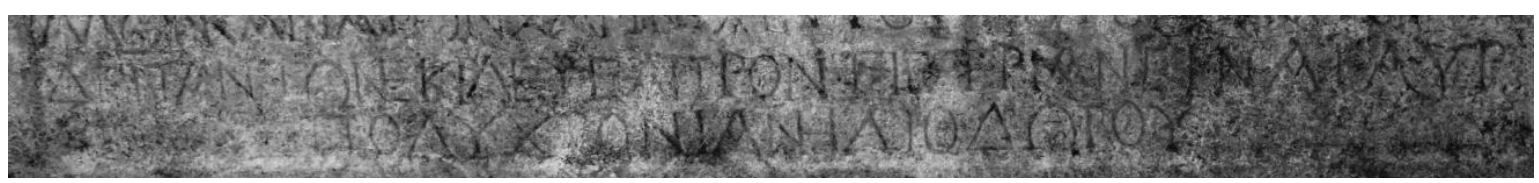

Fig. 3) The last two lines of the inscription.

This inscription belongs to the relatively small number of tomb inscriptions which are not formulated with standardised phrases. It is therefore no surprise that it contains more than only trivial information; the message of this inscription is unusual and expressed in an unusual manner. First of all, the person who has composed this inscription, made many orthographical ${ }^{10}$ and grammatical ${ }^{11}$ mistakes. It is pretty astounding to see that a member of the leading class had such a bad command of Greek language. In addition, the stonecutter, who engraved the text in the tabula ansata, made at

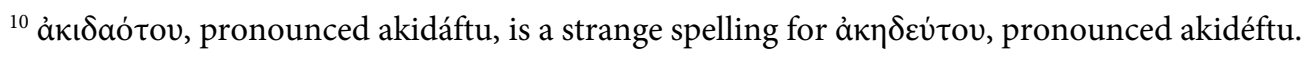

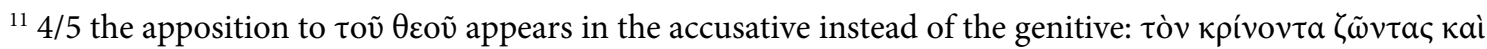

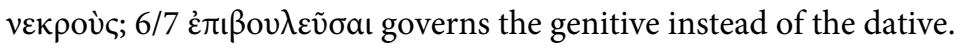


least two mistakes. ${ }^{12}$ This makes it difficult for the reader to understand the grammatical structure of longer passages, which are anything but elegantly and clearly phrased. Much more essential is that the inscription does not explicitly tell us the life circumstances of the man, whose corpse should be buried in this sarcophagus; there are only vague allusions, which stimulate curiosity, but it appears that the dead's son does not want to go into details. The lack of certain and concrete indications in regards to the precise dating of the inscription also makes the assessment of the historical situation more difficult.

As far as we are able to understand this text and its background, Eikadios, who is the son of a certain Heliodoros, implores the Christian community residing in Kios to take care that nobody will open the sarcophagus, that he has bought to bury his father, nor will do harm to it.

There are some indications to make us think that Eikadios's activities happened in turbulent times, which had heavily influencend the course of his and his father's life. We can infer from the wording

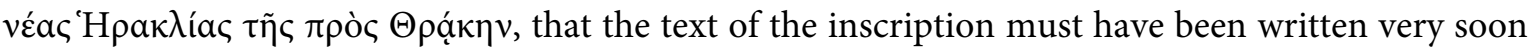
after the renaming of Perinthos as Herakleia-a name that persisted to our time in the form Ereğli. Diocletian not only renamed the city, but also established an imperial mint there. ${ }^{13}$ This may show a close connection between the city and the emperors. The renaming of the city occurred early in Diocletian's reign, at any rate before the $13^{\text {th }}$ of October, A.D. 286, when Diocletian (and Constantius) dispatched an imperial rescript from «Heraclea Thracum» to a certain Alexandria. ${ }^{14}$

The change of this city's name may have to do with Diocletian's stylization of himself as Iovius and of his co-emperor Maximianus as Herculius: the city of Perinthos may have changed its name to flatter Maximianus by referring to the empeor's heroic cognomen. ${ }^{15}$ The city's former name, Perinthos, was already closely, but not so explicitly linked with Herakles. According to local lore Perinthos was a companion and friend of the demigod; coins of the city of Perinthos depict Herakles and the hero Perinthos shaking hands. ${ }^{16}$ With the name change the Perinthians could express their sympathy

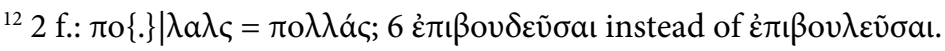

${ }^{13}$ Robert 1956, 594; Kuhoff 2001, 527 f.

${ }^{14}$ Cf. Fragmenta Vaticana no. 284: «proposita III id. Oct. Heraclea Thracum Maximo et Aquilinio conss.» (FIRA II ${ }^{2}, 526$ no. 284; Sayar 1998, 123 LZ 112). In the work of the geographer Ptolemaios from the $2^{\text {nd }}$ century

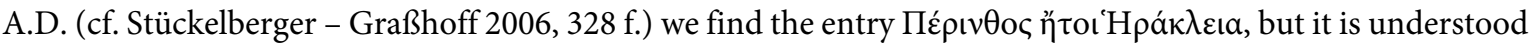

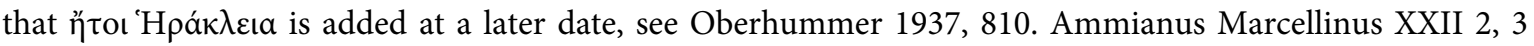
records that the older name of Herakleia was Perinthos: «Heracleam ingressus est Perinthum»; cf. the commentary of Den Boeft et alii 1995, 13 f. Cf. idem XXVII 4, 12: «Europa omnium ultima, praeter municipia urbibus nitet duabus, Apris et Perintho, quam Heracleam posteritas dixit». Zosimos also relates that in his days - at the end of the fifth century and the beginning of the sixth century-Perinthos was called by it's new

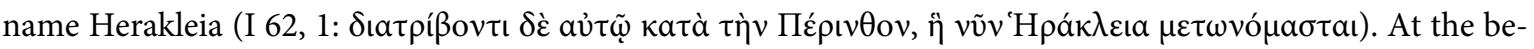
ginning of the seventh century Theophylaktos Simocatta records that in former times Herakleia was known as

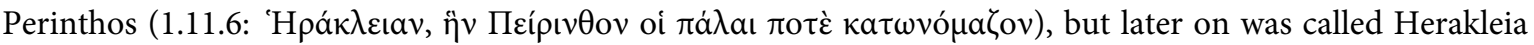

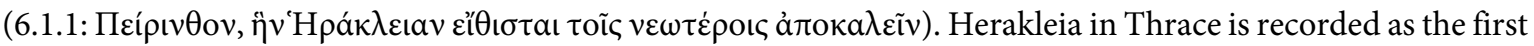

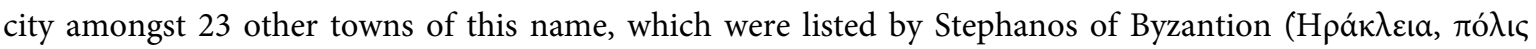

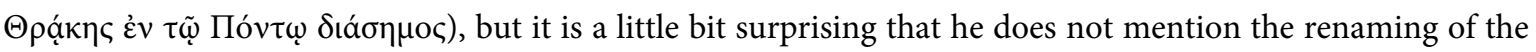
city in his article on Perinthos. Cf. Kuhoff 2001, 528.

${ }^{15}$ Kolb 1987, 63 f.; Bowman 2005, 70.

${ }^{16}$ The Scholion in Clem. Alex. protr. 50, 20 (S. 315 Stählin) related the story about Herakles' love affair with

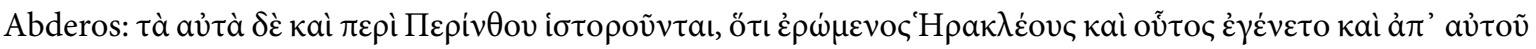


and gratitude not only for the Maximianus, but also for Diocletian and the first outlines of his new governmental system. The date of the introduction of the titles Iovius and Herculius is controversial, but as Kuhoff states, Maximianus's elevation to the rank of Augustus (1st of April, 286) is the most likely one. ${ }^{17}$

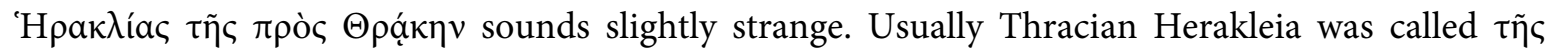

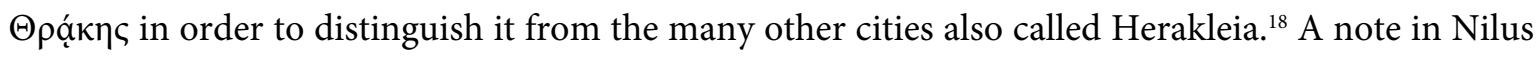
Doxapatrius's «Notitia Patriarchatuum et Locorum nomina immutata suggests how we have to un-

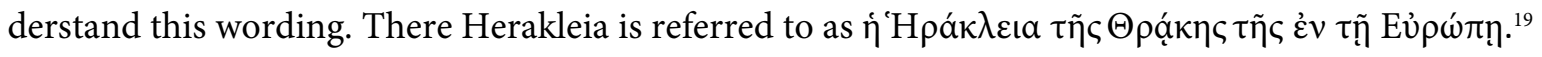
This entry leads us to the terminological problems which came up with Diocletian's provincial reorganisation. Nilus's formulation was designed to show that Thracian Herakleia, which at the time be-

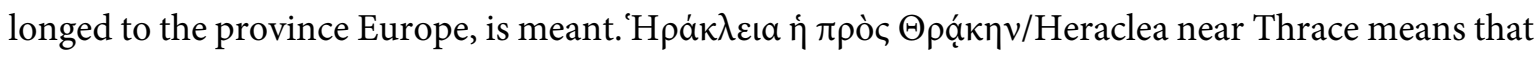
the city was no longer located in a province called Thrace, but lies near the province of Thrace. By Diocletian's division of the Roman Empire's provinces the former province of Thracia had been split up into four smaller provincial districts, called Thracia, Haemimontus, Rhodope and Europe. With this rearrangement Herakleia had become the capital of the province of Europe, but apparently, it bordered with the new smaller Diocletianic province of Thracia, which preserved the name of the old province. Diocletian's rearrangement of the Roman Empire's provinces had obscured new Herakleia's relationship with Thracia, at any rate at the time of its foundation. This explanation may provide a background explanation why Herakleia is described in this text as Herakleia near Thracia.

Unfortunately, like the renaming of Perinthos as Herakleia (between the $1^{\text {st }}$ of April and the $13^{\text {th }}$ of October, A.D. 286?), Diocletian's division of the former Thracian province into four new provinces cannot be exactly dated. This administrative reform was initiated around 293, but dragged on for years. In view of the scarce evidence it does not appear to be advisable to be more precise. ${ }^{20}$

Eikadios's father Heliodoros had been a councillor of Perinthos and the president of the city's gerusia, ${ }^{21}$ but finally he moved to Kios and died there as a servant of the Christian god. We do not know whether he had a special relationship with Kios or whether he had only sought refuge there. It is quite probable that he was a victim of the persecutions of the Christians initiated by Diocletian in February

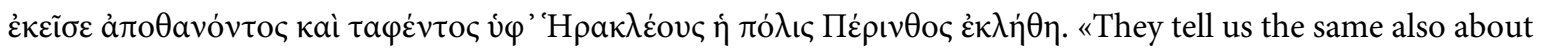
Perinthos, namely that he had become a beloved of Herakles and that then after he died and had been buried by Herakles, the city was called Perinthos after him». Ammianus Marcellinus XXII 8, 5: «civitatem quam Hercules conditam Perinthi comitis sui memoriae dedicavit». For coins showing Herakles and Perinthos shaking hands: Robert 1987, 99 n. 3, who rightly criticises Schönert-Geiß's misinterpretation of some Perinthian coins; Weiss 1984, 185; Weiss 1994, $325 \mathrm{f}$.

${ }^{17}$ Kuhoff 2001, 42.

${ }^{18}$ Notitiae Episcopatuum (ed. J. Darrouzès, Paris 1981) several times records the name of city as $\mu \eta \tau \rho o ́ \pi o \lambda ı \varsigma$

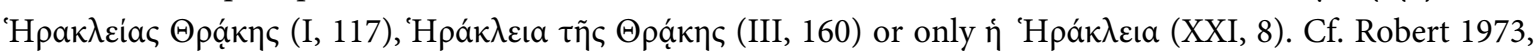
438-442, who discusses the problems to identify the various cities called Herakleia, when a ${ }^{\circ} \rho \alpha \kappa \lambda \varepsilon ı \dot{\omega} \tau \eta \varsigma$ is mentioned in an inscription.

${ }^{19}$ In Nilus Doxapatrius’ «Notitia Patriarchatuum et Locorum Nomina Immutata〉 (ed. G. Parthey), Berlin 1866, 298 no. 233.

${ }^{20}$ Barnes 1982, 201-208: The Verona List, and 209-225, esp. 224 on Thracia, who writes: «and by the fourth century was divided into four smaller provinces».

${ }^{21}$ This is the first testimony for the existence of a $\gamma \varepsilon \rho o v \sigma i \alpha$ in Perinthos. 
303. Already in their first imperial letter the tetrarchs had ordered that Christians should be removed from the senatorial, equestrian, and curial class and also from the offices they hold. ${ }^{22}$ Because of Herakleia's (Perinthos's) proximity to Nikomedeia, where Diocletian had his main residence, it is quite clear that the orders of this decree were fully implemented there. Eikadios does not call himself coun-

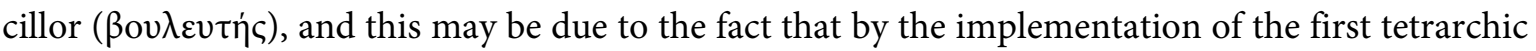
decree against the Christians not only Heliodoros but also his descendants lost their curial status. In the end, we cannot even be sure that Heliodoros died a natural death. At any rate, Herakleia/Perin-

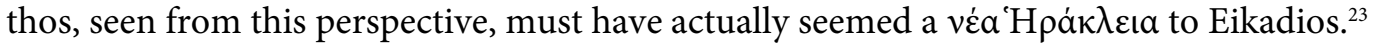

Since after Heliodoros' death his corpse was still unburied, his son Eikadios intervened, bought this sarcophagus for the burial of his father, had the inscription engraved and appointed his sister Polychronia guardian of the sarcophagus and of the dispositions he had made. From this we may conclude that Eikadios did not live in Kios-perhaps he was, like his father, a citizen and inhabitant of Perinthos-, whereas his sister Polychronia may have been in residence in Kios.

We don't know very much about the emergence of Herakleia's Christian community. By asserting that the city's first bishop Apelles was ordained and consecrated by Andrew the apostle, the brother of St. Peter, ${ }^{24}$ the bishopric of Perinthos/Herakleia claimed an apostolic origin. Till the elevation of Byzantion to the rank of a capital of the Eastern Roman Empire under the name of Constantinople in 330, the bishop of Perinthos/Herakleia was the supervisor (metropolitan) of the Byzantian bishop. That is why in later times the Perinthian bishop kept the privilege to enthrone the Patriarch of Constantinople. We hear of an impressive number of «Perinthian〉 martyrs being either citizens of Perinthos or foreigners who suffered death in the city. Regarding the persecutions of Diocletian and Licinius the Acts of the Martyrs name numerous Herakleian witnesses of faith $\cdot{ }^{25}$ Heliodoros may have moved in their circles.

1 Eỉxádıç: Rudolf Hirzel 1927, 39 has compiled a list of those personal names, which refer to the day on which someone was born. Such names were in particular chosen when the birthday coincided with a day that was sacred to an important goddess or was in some way remarkable. Hirzel mentions that the 20th was a holy day devoted to the veneration of Apollon. ${ }^{26}$ However, we always have to

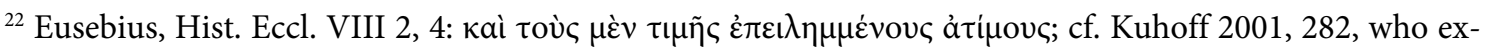
plains this with «Ausstoßung der Christen aus den drei ordines, also dem Senatoren-, Ritter- und Dekurionenstand». Cf. also Lactantius, De mort. pers. 13: "postridie prosopositum est edictum quo cavebatur, ut religionis illius homines carerent omni honore ac dignitate, tormentis subiecti essent, ex quocumque ordine aut gradu venirent, ...».

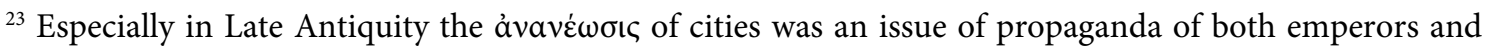

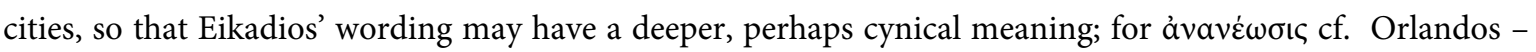

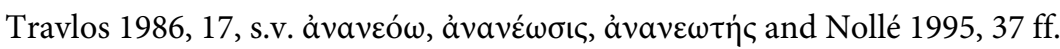

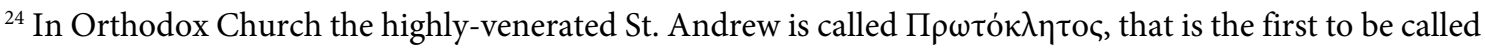
by Jesus into his service.

${ }^{25}$ All relevant facts are collected in the paper of Külzer 2014, 440 f., esp. 440: «Über die Größe der christlichen Gemeinden in Ostthrakien in den ersten Jahrhuznderten lassen sich keine verläßlichen Angaben machen, doch muß das Christentum in Perinthos/Herakleia schon damals eine wichtige Rolle gespielt haben, sind doch zahlreiche Märtyrer mit der Stadt verbunden».

${ }^{26}$ Further testimonies for this name were collected by Içten - Engelmann 1992, 288 Nr. 11: «Der Verstor-

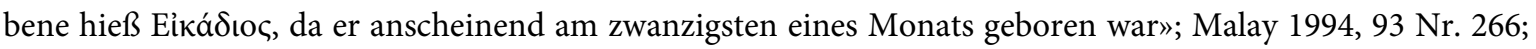


reckon with the possibility that the name was traditional in the family.

1 'H $\lambda_{\text {ıo }} \delta \omega \rho$ 'ov: Louis Robert has shown that, in accordance with the rareness of the cult of Helios in most parts of the Greek World, the name'H $\lambda$ ıó $\delta \omega \rho$ o s was only widespread in Rhodes, Egypt and the Levant. ${ }^{27}$ However, in the last decades of the $3 \mathrm{rd}$ and the first decades of the 4th $\mathrm{c}$. AD the increasing veneration of the sun god, not least by the Roman emperors, may have found a reflection in the choice of this or other Helio-names.

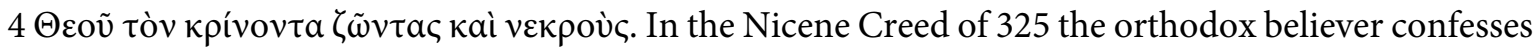
that he believes that Jesus Christus «from thence shall come to judge the quick and the dead» (кai

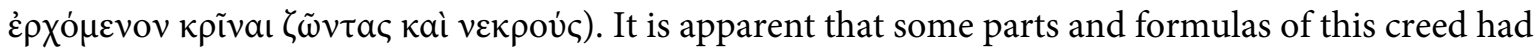
been in use, before the $\sigma \dot{v} \mu \beta 0 \lambda$ ov was carefully worded during the famous first Council of Nicaea. It may be that the grammatical mistake was made, as the author of this tomb inscription was accus-

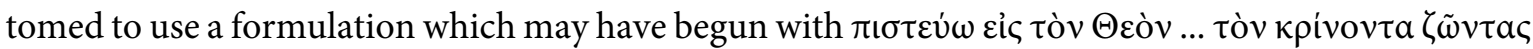
kaì vekpoúc in Christian liturgy. This formula is found in some tomb inscriptions from Herakleia/Perinthos and other cities, ${ }^{28}$ but all of them seem to be more recent than the Nicene Creed and to be influenced by it.

$6 \dot{\varepsilon} \pi ß{ }$

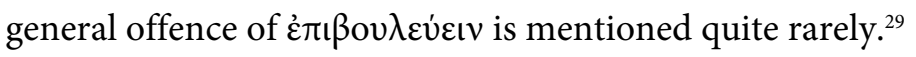

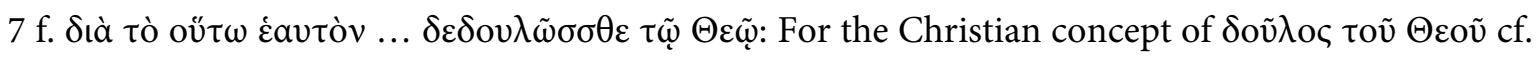

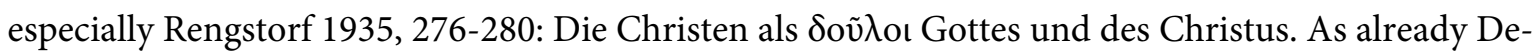
issmann has explained, the Christian idea that men were slaves of god is closely aligned with Greek (and Roman) concepts of manumission..$^{30}$ Very often slaves were freed in a way that owner and slave went to a nearby sanctuary where the owner solds the slave to a god. In reality the slaveholder was paid with the slave's savings. Although the slave became property of the god, he wasn't treated as a slave but as a protégé of the god and his sanctuary. ${ }^{31}$ In Christian thinking Jesus has paid the ransom

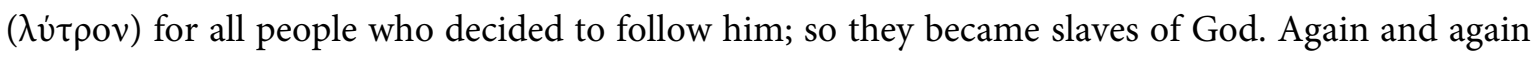

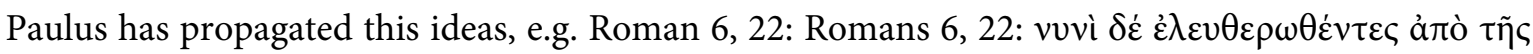

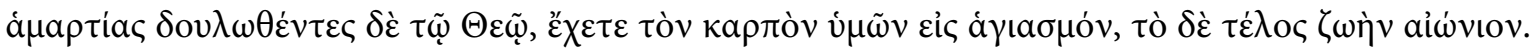
«But now that you have been set free from sin and have become slaves of God, the benefit you reap leads to holiness, and the result is eternal life». On the other hand we shouldn't forget that the idea

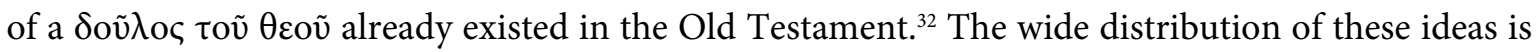

TAM V 3, Nr. 1669; Masson 1997, 71; Catling 2004-2009, 408.

${ }^{27}$ Robert 1973, 443; ebenso Catling - Kanavou 2007, 112. Parker 2000, 67 discusses a case, where Heliodoros is a translation of «slave of Shemesh».

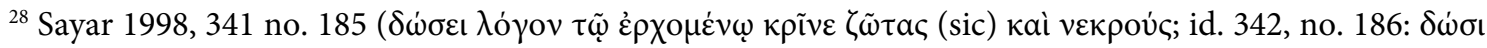

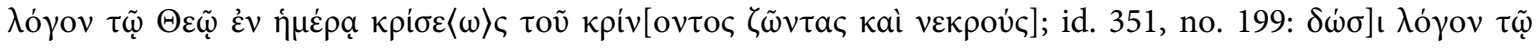

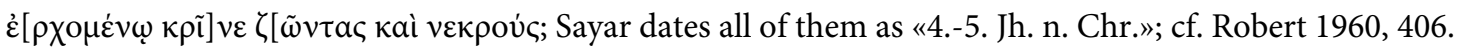

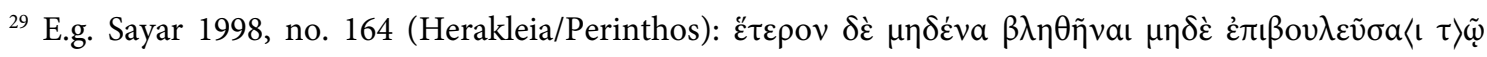

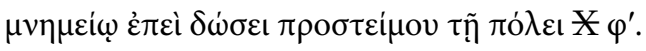

${ }^{30}$ Deissmann 1923, 270-287. For a contemporary evaluation of Deissmann's explanation cf. Klauck 2003, 89-92: Befreiung aus der Sklaverei.

${ }^{31}$ Cf. e.g. Bömer 1960.

${ }^{32}$ E.g. Genesis 26, 24; Isaias 49, 3; vgl. dazu auch Coşkun 2013, 
reflected by the frequency of the name Theodoulos. ${ }^{33}$

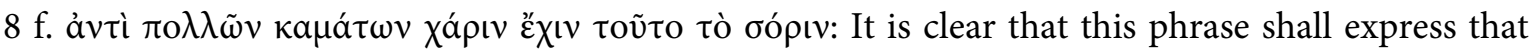

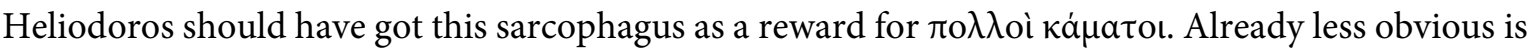
what precisely ká $\mu \alpha \tau o$ means. Does the word very generally refer to the troubles of life or shall it allude to Heliodoros's special fate by expressing Christian views of life? Since ká $\mu a \tau o$ is not uncommonly used in pagan texts in a variety of contexts, we cannot see a particular Christian thinking behind the use of this phrase. In a number of Greek epigrams, which explain objects dedicated to a

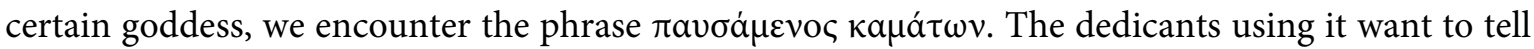
us that they have definitely finished their hard working-life, e.g. the peasant Parmis and the three Cretan weavers Autonoma, Boiskion, and Meliteia. ${ }^{34}$ Quite often an untimely death was interpreted

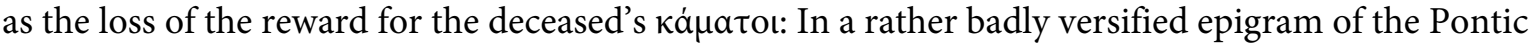
city of Nea Klaudiopolis we hear of the fate of a mother who died before she could enjoy the fruits of her laborious care for her family. ${ }^{35}$ The idea that children not only had to honour their parents, when they are still alive, for their ká $\mu \alpha \tau o$, but also had to bury them with dignity, when they had passed away, for the same reason, is expressed in the following epigram found in the territory of Dorylaion:

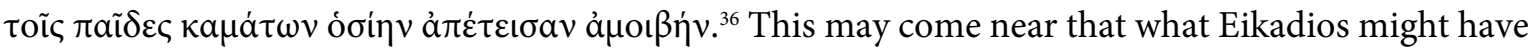
thought when he had composed the text of the tomb inscription discussed here. However, as life was

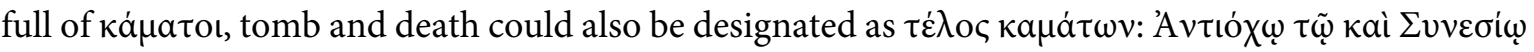

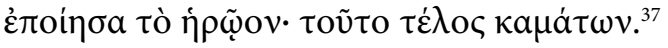

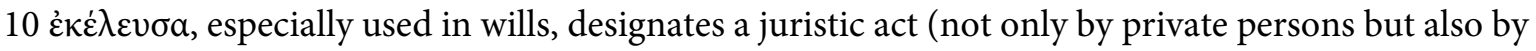
magistrates) and is equal to the Latin <iussi.${ }^{38}$

$10 \pi \rho \circ \tau i \sigma \tau \rho \iota \alpha / \varphi \rho o v \tau i \sigma \tau \rho \iota \alpha$ may be used in the sense of «curator〉 or «tutor.${ }^{39}$ For the spelling (regression of an aspirata towards the tenuis) cf. Dieterich 1898, 84 f.; Brixhe 1984, 43.

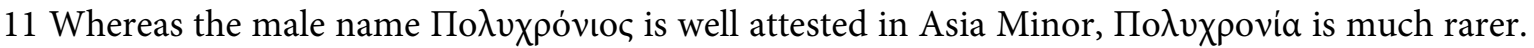
With this name the parents, who called their daughter Polychronia, expressed their hope that their child should enjoy a long life..$^{40}$

\footnotetext{
${ }^{33}$ Cf. Coşkun 2013, 103.

${ }^{34}$ Parmis: Anth. Pal. VI 95 by Antiphilos of Byzantion; cf. Müller 1935, 45 with a short commentary and some further examples for the usage of this phrase. Cretan weavers: Anth. Pal. VI 289 by Leonidas of Tarentum.

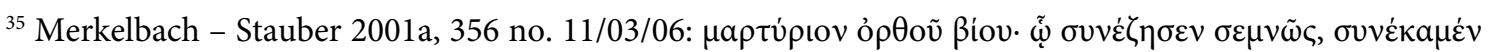

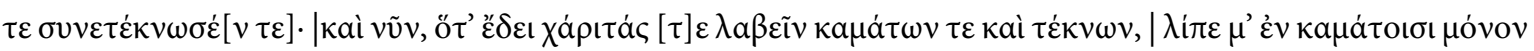

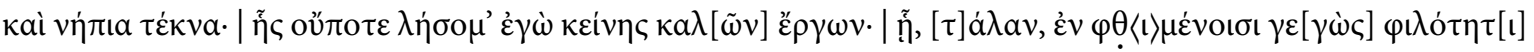

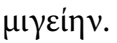

${ }^{36}$ Merkelbach - Stauber 2001b, 318 no. 16/34/29.

${ }^{37} \mathrm{IG} \mathrm{II}^{2}$, no. 13209.

${ }^{38}$ Cf. Heberdey - Wilhelm 1896, 54 f. no. 123 (Hagel - Tomaschitz 1998, 134 no. 10; Kanytelis): кa '

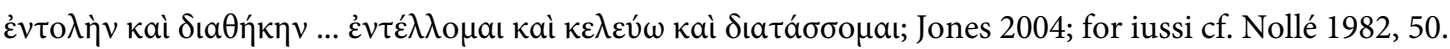

${ }^{39}$ Cf. Balland 1981, 87 n. 74 and 75; Nollé 2001, 514 no. 190.

${ }^{40}$ Cf. Corsten 1991, 180 f. no. 154.
} 


\section{Bibliography}

Asgari 1977

Balland 1981

Barnes 1982

Bowman 2005

Bömer 1960

Börker 1975

Bredow 2000

Brixhe 1984

Catling - Kanavou 2007

Catling 2009

Corsten 1991

Coşkun 2013

Deissmann 1923

Den Boeft et alii 1995

Dieterich 1898

Gebauer 2002

Hagel - Tomaschitz 1998

Heberdey - Wilhelm 1896
N. Asgari, Die Halbfabrikate kleinasiatischer Girlandensarkophage und ihre Herkunft, AA 1977, 329-380.

A. Balland, Fouilles de Xanthos VII. Inscriptions d'époque impériale du Létôon, Paris 1981.

T. Barnes, The New Empire of Diocletian and Constantine, Cambridge (Mass.)/London 1982.

A. K. Bowman, Diocletian and the first tetrarchy, A.D. 284-305, in: CAH 12: The Crisis of Empire, A.D. 193-337, Cambridge 2005, 6789.

F. Bömer, Untersuchungen über die Religion der Sklaven in Griechenland und Rom 2: Die sogenannte sakrale Freilassung in Grie-

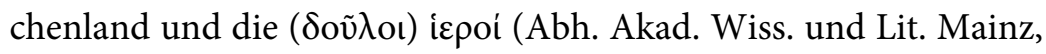
Geistes- und sozialwiss. Kl. 1), Wiesbaden 1960.

Ch. Börker, Bukranion und Bukephalion, AA 1975, 244-250.

I. von Bredow, Perinthos, DNP 9, 2000, 574-575.

C. Brixhe, Essai sur le grec anatolien au début de notre ère, Nancy 1984.

R. W. V. Catling - N. Kanavou, The Gravestone of Meniketes Son of Menestheus: IPrusa 1028 and 1054, ZPE 163, 2007, 103-117.

R. W. V. Catling, Attalid troops at Thermon. A reappraisal of IG IX 12 (1) 60, Horos 17-21, 2004-2009, 397-439.

Th. Corsten, Die Inschriften von Prusa ad Olympum (IK 39), Bonn 1991.

A. Coşkun, Histoire par les noms in Ancient Galatia, in: R. Parker (Hrsg.), Personal Names in Ancient Anatolia, Oxford 2013, 79-106.

A. Deissmann, Licht vom Osten. Das Neue Testament und die neuentdecken Texte der hellenistisch-römischen Welt, Tübingen ${ }^{4} 1923$. J. den Boeft - J.W. Drijvers - D. den Hengst - H.C. Teitler, Philological and Historical Commentary on Ammianus Marcellinus, Groningen 1995.

K. Dieterich, Untersuchungen zur Geschichte der griechischen Sprache von der hellenistischen Zeit bis zum 10. Jahrhundert n. Chr., Leipzig 1898.

J. Gebauer, Pompe und Thysia. Attische Tieropferdarstellungen auf schwarz- und rotfigurigen Vasen, Münster 2002.

St. Hagel - K. Tomaschitz, Repertorium der westkilikischen Inschriften (Österr. Akad. Wiss., philos.-histor. Klasse, Denkschr. 265), Wien 1998.

R. Heberdey - A. Wilhelm, Reisen in Kilikien ausgeführt 1891 und 1892 (Denkschr. Kais. Akad. Wiss. Wien, Phil.-hist. Kl., 44, 6), Wien 
Hirzel 1927

İçten - Engelmann 1992

Jones 2004

Klauck 2003

Koch - Sichtermann 1982

Kolb 1987

Kuhoff 2001

Külzer 2014

Malay 1994

Masson 1997

Merkelbach - Stauber

2001a

Merkelbach - Stauber

$2001 b$

Müller 1935

Nollé 1995

Nollé 2001

Oberhummer 1912

Oberhummer 1937
1896.

R. Hirzel, Der Name. Ein Beitrag zu seiner Geschichte im Altertum und besonders bei den Griechen (Sächs. Akad. Wiss., Phil.-hist. Kl., Abh. 36), Leipzig ${ }^{2} 1927$.

Ç. İçten - H. Engelmann, Inschriften aus Ephesos und Umgebung, ZPE 91, 1992, 283-295.

Ch. P. Jones, A Roman Will in Cappadocia, EA 37, 2004, 95-100.

H.-J. Klauck, Religion und Gesellschaft im frühen Christentum. Neutestamentliche Studien, Tübingen 2003.

G. Koch - H. Sichtermann, Römische Sarkophage (HdA), München 1982.

F. Kolb, Diocletian und die Erste Tetrarchie. Improvisation oder Experiment in der Organisation monarchischer Herrschaft? (Untersuchungen zur antiken Literatur und Geschichte, Band 27) Berlin New York 1987.

W. Kuhoff, Diokletian und die Epoche der Tetrarchie. Das römische Reich zwischen Krisenbewältigung und Neuaufbau (284-313 n. Chr.), Frankfurt am Main etc. 2001.

A. Külzer, Die Metropolis von Herakleia in Ostthrakien (Marmaraereğlisi). Notizen zur Kirchengeschichte in byzantinischer Zeit, in: K. Katerelos - A. Glavinas - G. Larentzakis (Hrsg.), $\Sigma$ KEYO $\Sigma$ EI $\Sigma$ TIMHN. Festschrift zum 25-jährigen Jubiläum der Bischofsweihe und 20-jährigen Jubiläum der Inthronisation zum Metropoliten von Austria ... Dr. Michael Staikos, Athen 2011 (2014), 473-483.

H. Malay, Greek and Latin Inscriptions in the Manisa Museum, Wien 1994.

O. Masson, Nouvelles notes d'anthroponymie grecque, ZPE 119, 1997, 71.

R. Merkelbach - J. Stauber, Steinepigramme aus dem griechischen Osten 2. Die Nordküste Kleinasiens (Marmarameer und Pontos), München/Leipzig 2001.

R. Merkelbach - J. Stauber, Steinepigramme aus dem griechischen Osten 3. Der «Ferne Osten» und das Landesinnere bis zum Tauros, München/Leipzig 2001.

K. Müller, Die Epigramme des Antiphilos von Byzanz, Berlin 1935.

J. Nollé, Stadtsanierung im Altertum, in: Die Alte Stadt 22, 1995, 3050.

J. Nollé, Side im Altertum. Geschichte und Zeugnisse 2 (IK 44), Bonn 2001.

E. Oberhummer, Herakleia (8), RE VIII $1,1912,429$.

E. Oberhummer, Perinthos, RE XIX $1,1937,802-813$. 
Orlandos 1986

Rengstorf 1935

Robert 1956

Robert 1973

Sağır - Uzunoğlu

- Hançer 2011

Sayar 1998

Soustal 1991

Weiss 1984

Weiss 1994
Robert 1960

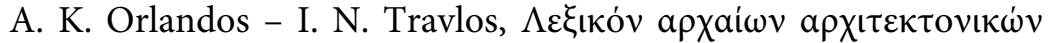
ó $\omega \omega v$, Athen 1986.

Rengstorf, in: G. Kittel, Theologisches Wörterbuch zum Neuen Tes-

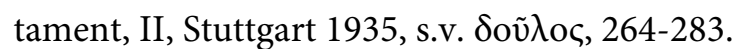

L. Robert, Sur un tissu récemment publié, Cahiers archéologiques 8 , 1956, 27-36 (= id., OMS 7, Amsterdam 1990, 589-598).

L. Robert, Hellenica 11-12, Paris 1960.

L. Robert, Sur des inscriptions de Délos, in: Études Déliennes (BCH Suppl. 1), 1973, 435-489.

E. Sağır - H. Uzunoğlu - K. Hançer, Three New Sarcophagi from Kios (Gemlik), Gephyra 8, 2011, 31-44.

M. H. Sayar, Perinthos-Herakleia (Marmara Ereğlisi) und Umgebung. Geschichte, Testimonien, griechische und lateinische Inschriften, (Österreichische Akademie der Wissenschaften, phil.-hist.

Kl. Denkschriften 269. Veröffentlichungen der Kleinasiatischen Kommission 9), Wien 1998.

P. Soustal, Tabula Imperii Byzantini 6: Thrakien. Thrake, Rodope und Haimimontos (Österreichische Akademie der Wissenschaften, phil.-hist. Kl. Denkschriften 221), Wien 1991.

Stückelberger - Graßhoff 2006 Klaudios Ptolemaios. Handbuch der Geographie. Griechisch Deutsch. Herausgegeben von A. Stückelberger und G. Graßhoff, 1. Teil, Basel 2006.

P. Weiss, Lebendiger Mythos. Gründerheroen und städtische Gründungstraditionen im griechisch-römischen Osten, WJA 10, 1984, 179-208.

P. Weiss, LIMC VII 1, 1994, s.v. Perinthos I, 325-332.

\section{Heliodoros veya "Büyük Kıyım” Sırasında Perinthos'lu bir Hıristiyanın Kaderi Özet}

Bu makale, Gemlik’te (antik Kios kenti) bir kaç yıl önce bulunmuş olan bir lahdi ele almaktadır. Lahit, pek çok ortografik ve gramatik hatası bulunan uzun bir yazıt taşımaktadır. Eikadios isimli birisi bu lahdi Trakya Herakleia'sinda (Perinthos) bouleutes ve gerousiarkhes olan babası Heliodoros'un gömülmesi için satın almıştır. Kios'ta bir Hıristiyan olarak ölmüş olan Heliodoros, Eikadios oraya geldiğinde yazıta göre hala gömülmemiştir. Eikadios, babası için bir mezar yeri satın almış ve babasının gömülmesiyle ilgilenmiştir. Bu yazıtta Eikadios Kios’taki Hırıstiyan topluluğundan lahdin korunmasını istemekte ve ayrıca kızkardeşini gömü yeri ve lahdin gözeticisi olarak görevlendirmektedir. Perinthos isminin yazıtta "Yeni Herakleia" olarak değişmesine ve Trakya eyaletinin dört alt eyalete bölünmesine istinaden yazıtı İ.S. 293 yılı sonrasındaki bir zamana tarihleyebiliriz. Yazıtla ilgili diğer gözlemlerimiz Heliodoros'un ölümünün Şubat 303 ile Şubat 313’teki Milano Fermanı arasında Roma İmparatorluğu'nda meydana gelen büyük Hırıstiyan kıyımı sırasında gerçekleştiğini göstermektedir. Pek çok şey karanlıkta kalmış olsa da, bu yazıt Büyük Kıyım sırasında Hıristiyanların durumunu gösteren önemli yeni bir belge niteliğindedir. 
Yazıtın Çevirisi: Pek çok hayırseverliği ve iyilikte aşılmazlğ̆ı sayesinde Trakya yakınındaki Nea Herakleia'nın meclis üyesi ve yaşllar meclisi başkan olan Heliodoros'un oğlu, ben Aurelius Eikadios, yaşayanları ve ölüleri yargılayan Tanrı'nın kullarına yalvarıyorum ki hiç kimse (bu lahdi) açmasın ve hiç kimse (henüz) defnedilmemiş olan babama karşı saygısızlık etmesin, çünkü o buraya (Kios'a) geldikten sonra kendisini Tanrı'nın bir kölesi yapmıştır ve böylece o çektiği bütün sıkıntılarına karşılık bu lahde sahip olacaktır. Ben, Heliodoros'un kızı Aurelia Polykhronia'nın bütün bu düzenlemelerin koruyucusu olmasinı emrettim.

Anahtar Sözcükler: Diocletianus; Diocletianus'un Büyük Hıristiyan Kıyımı; Gerusia; Herakleia/Perinthos/Marmara Ereğlisi; Kios; İznik Amentüsü.

\section{Heliodoros or the Fate of a Christian Councilman of Perinthos During the Great Persecution}

Abstract

This paper discusses a sarcophagus that was found in Gemlik (the ancient city of Kios) some years ago. It bears a longer than usual inscription with many orthographical and some grammatical errors. A certain Eikadios bought the sarcophagus for the burial of his father Heliodoros, who had been a bouleutes and gerousiarches of the city of Thracian Herakleia (Perinthos). In Kios Heliodoros had died as a Christian, but was still unburied, when Eikadios had come there. He had acquired a burial place for him and had taken care for his father's entombment. In the inscription Eikadios implores the Christian community of Kios to provide for the protection of the sarcophagus, and additionally appointed his sister to a guardian of the burial place and the sarcophagus. By allusions to the name change of Perinthos-which in the inscription is referred to as «New Herakleia`- and to the splitting up of the province Thracia into four subprovinces, we can date the inscription into the period after AD 293. Other observations suggest that the death of Heliodoros happened during the last noteworthy persecution of Christians in the Roman Empire, that is in the time between February 303 and the so-called Edict of Milan (February 313). Although many things remain obscure, this inscription is an important new testimony for the situation of Christians during the Great Persecution.

Keywords: Diocletian; Diocletian's Persecution of Christians; Gerusia; Herakleia/Perinthos/Marmara Ereğlisi; Kios; Nicene Creed. 


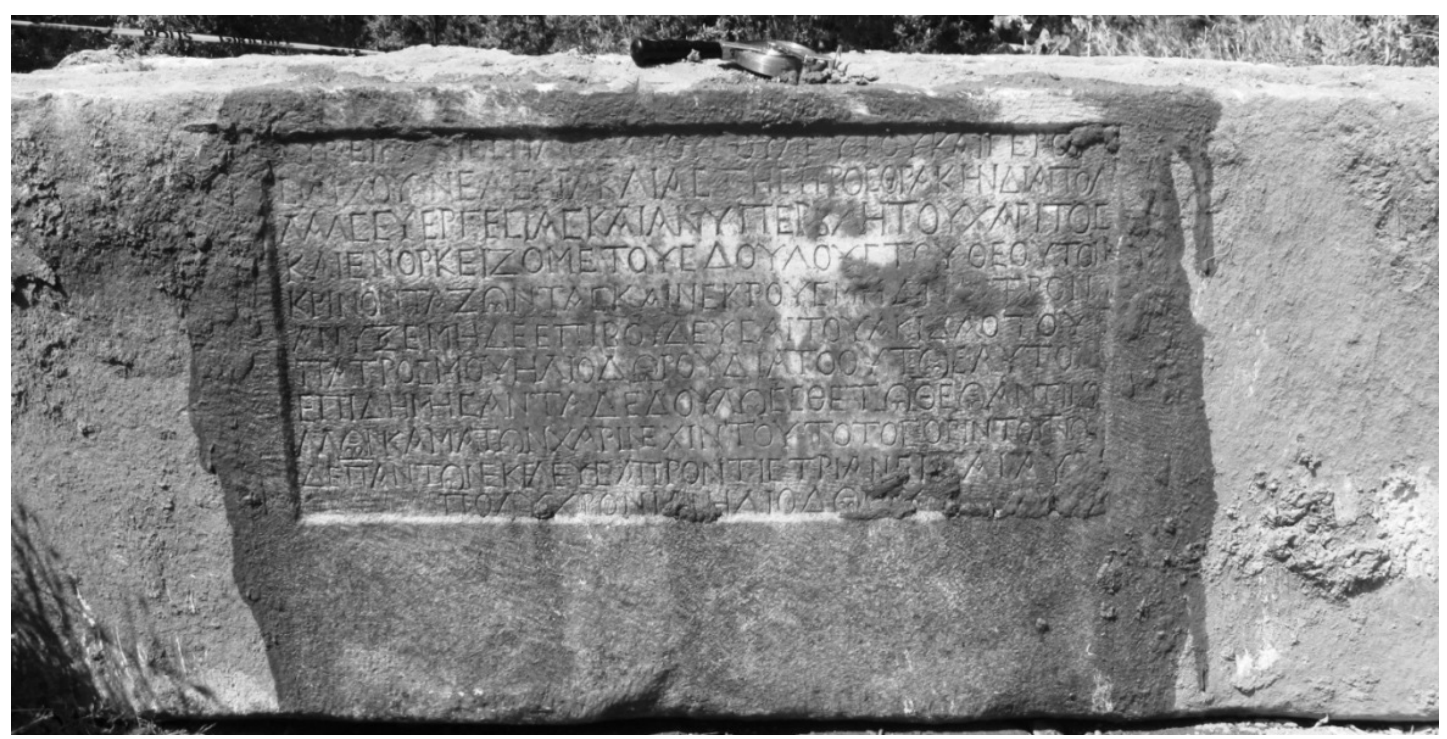

Fig. 4

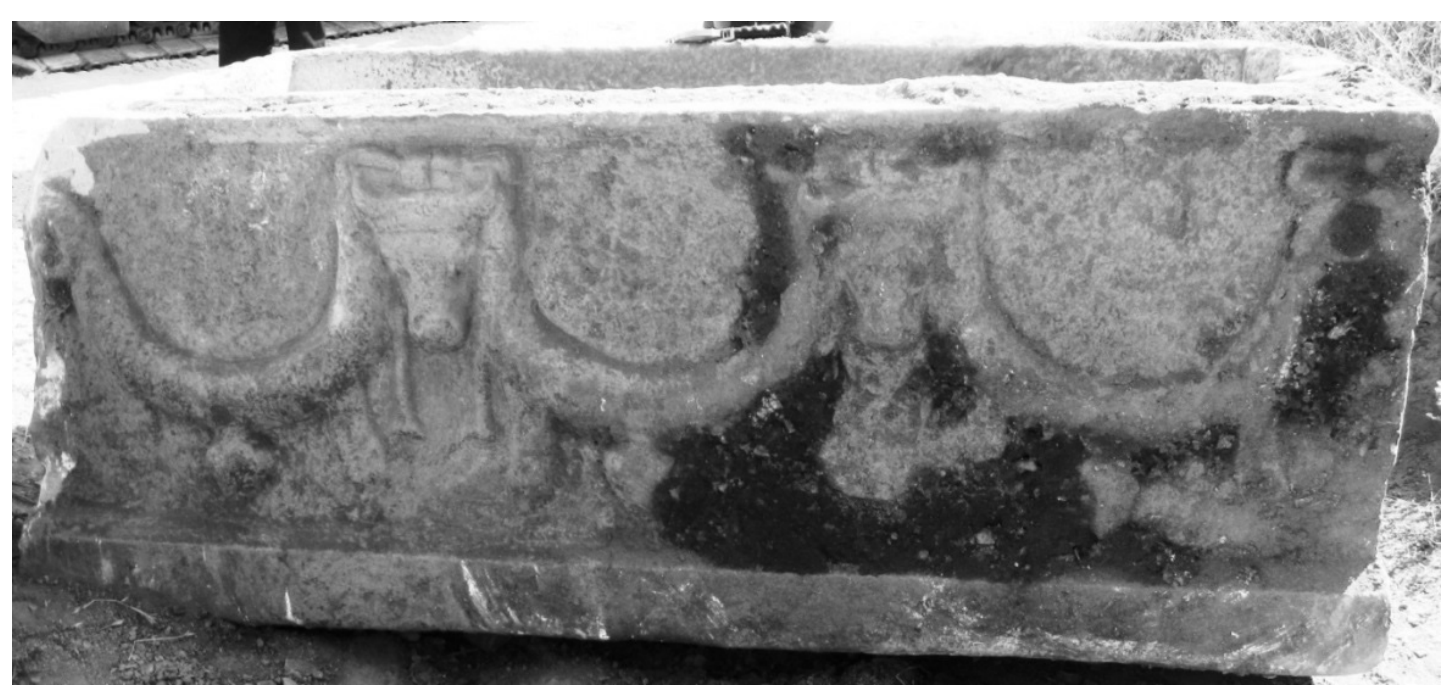

Fig. 5

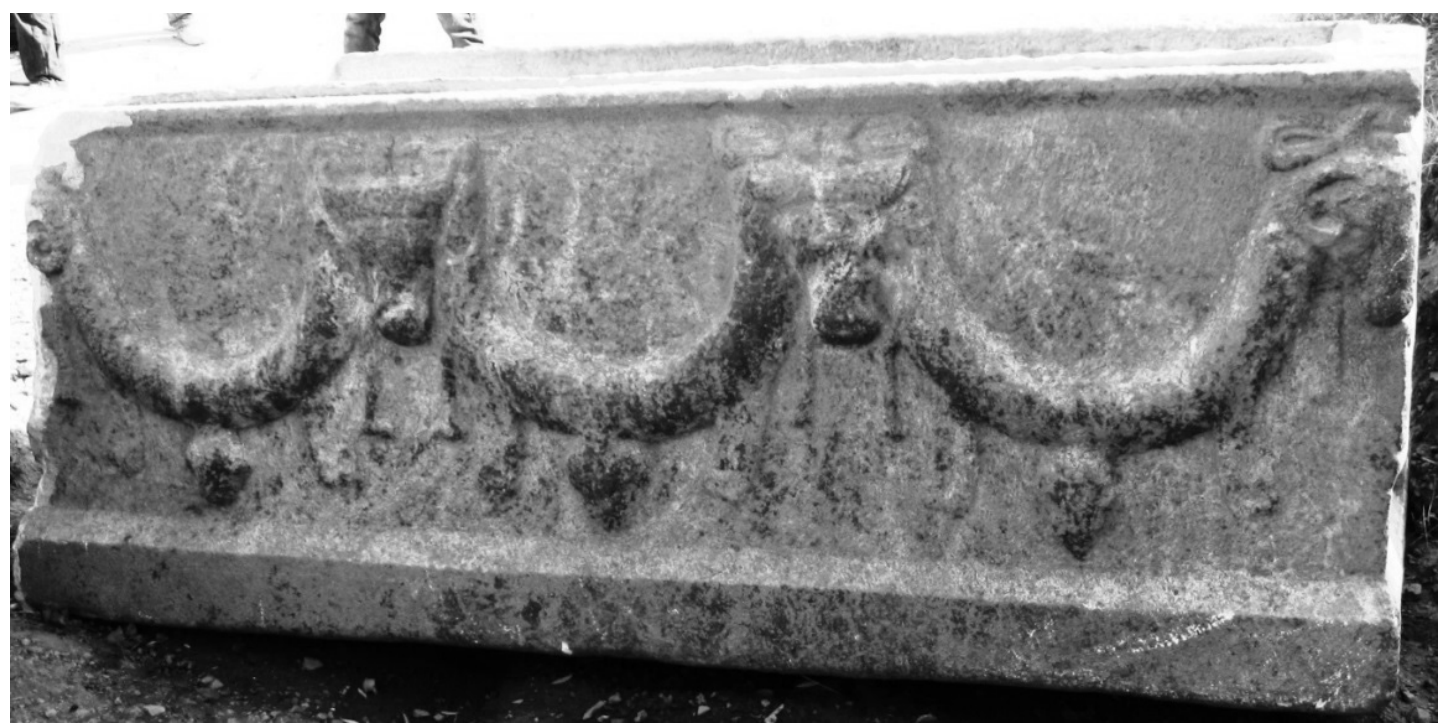

Fig. 6 


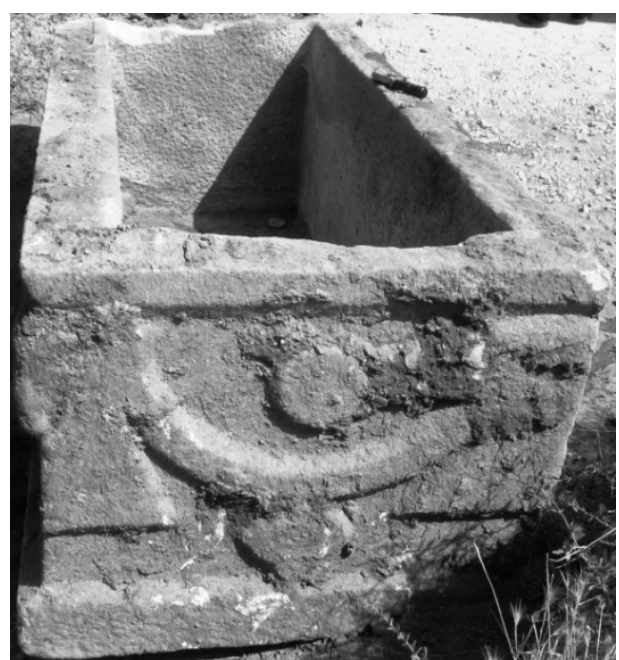

Fig. 7

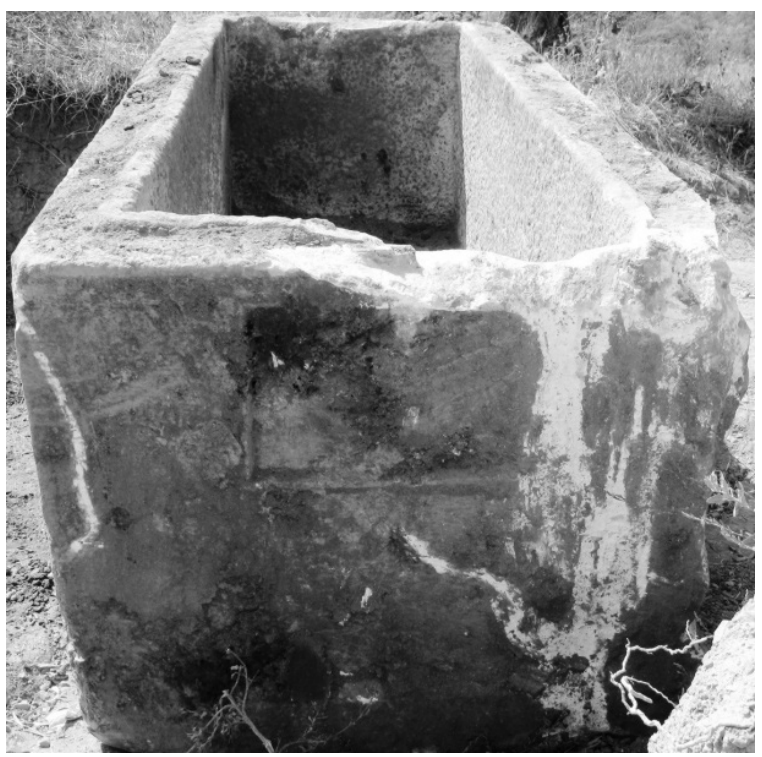

Fig. 9

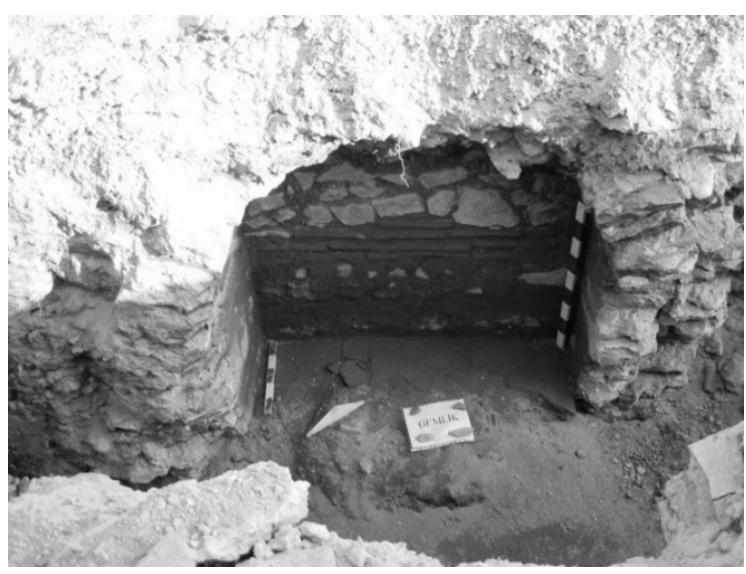

Fig. 11

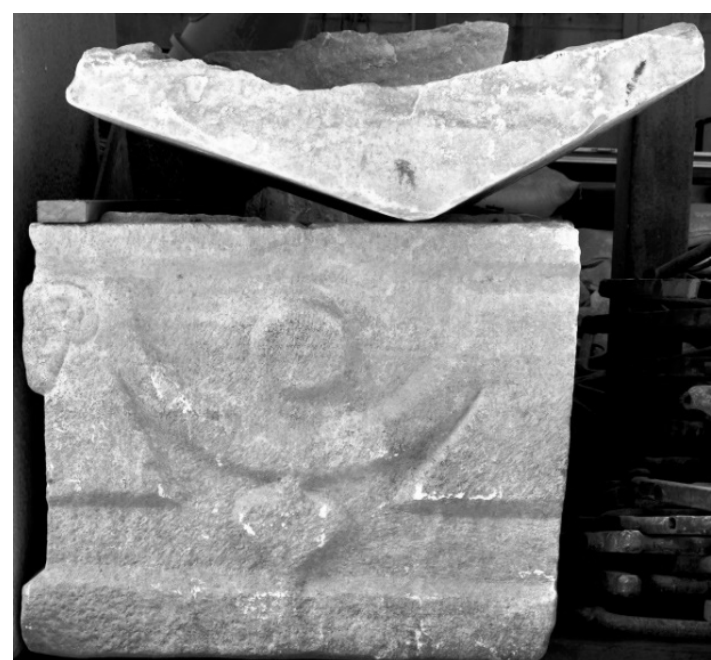

Fig. 8

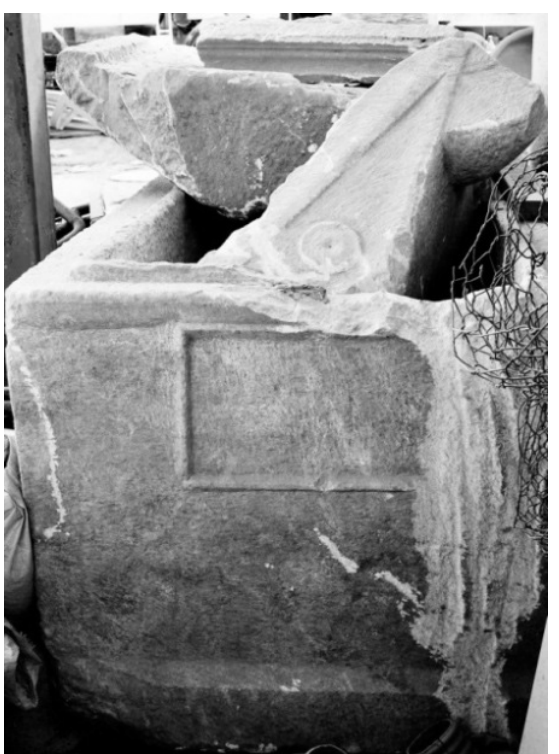

Fig. 10

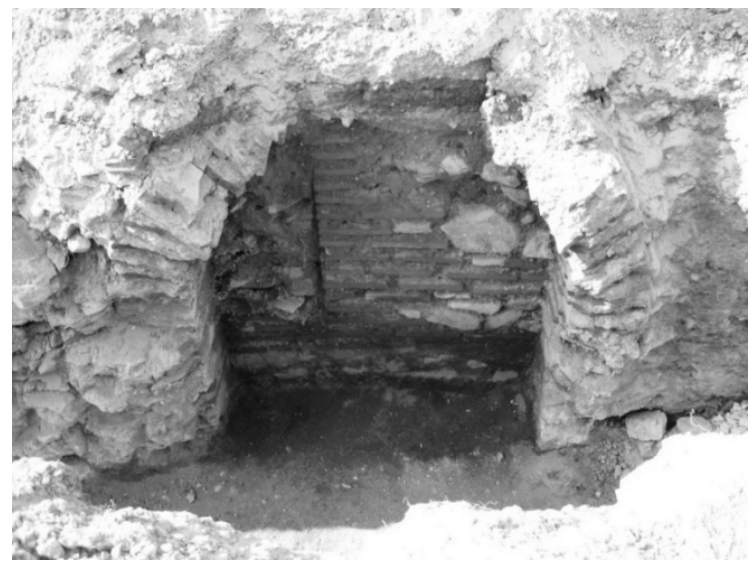

Fig. 12 


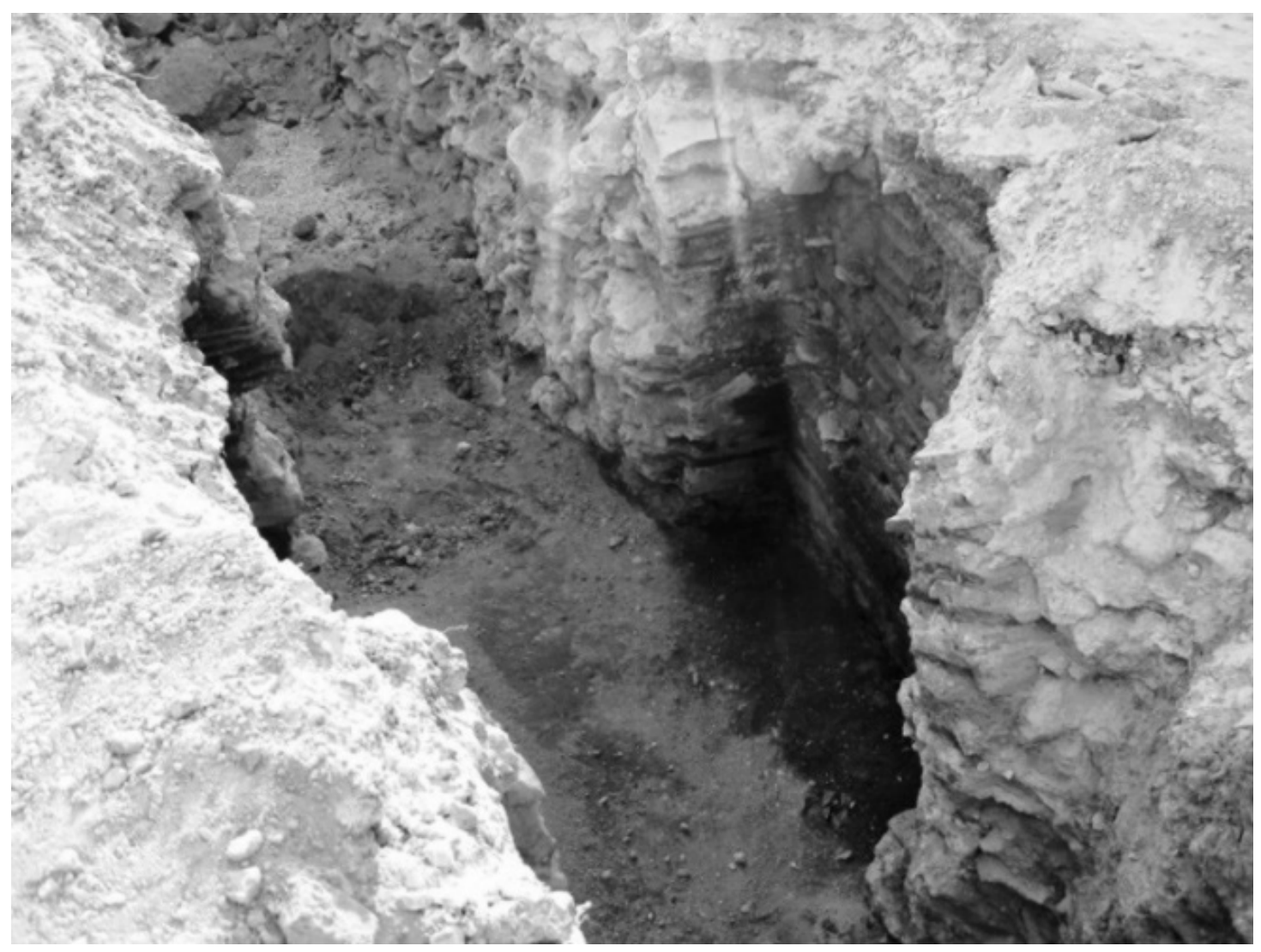

Fig. 13

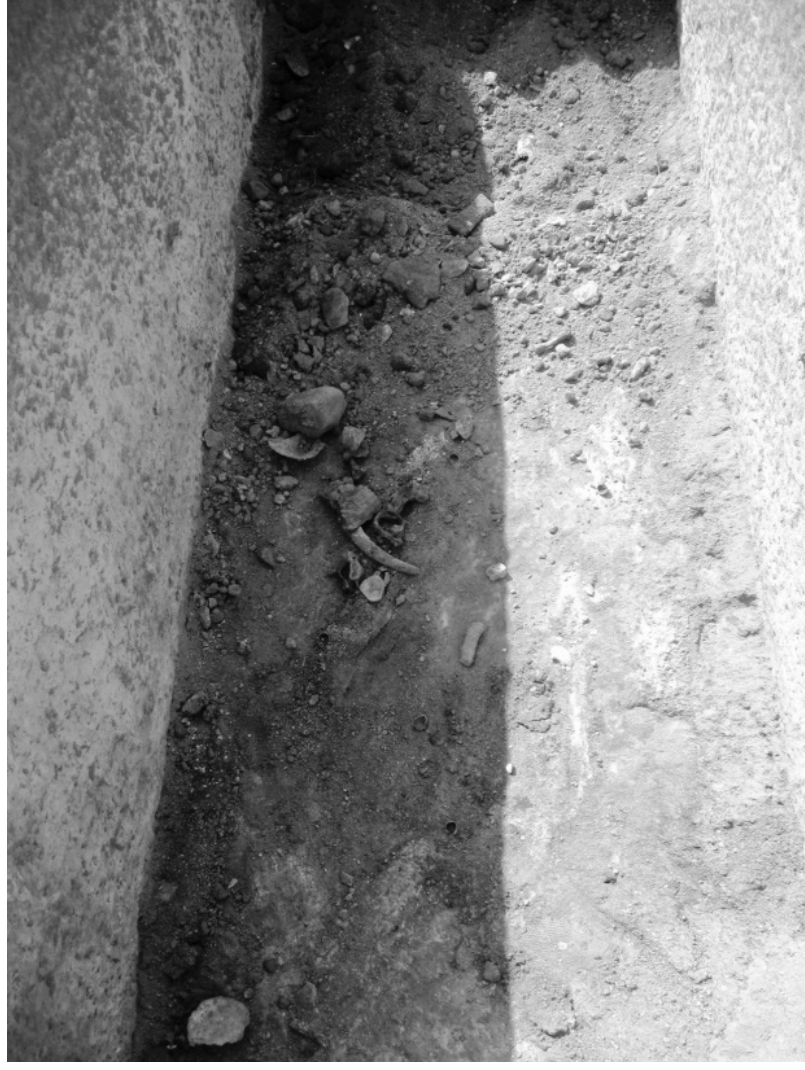

Fig. 14

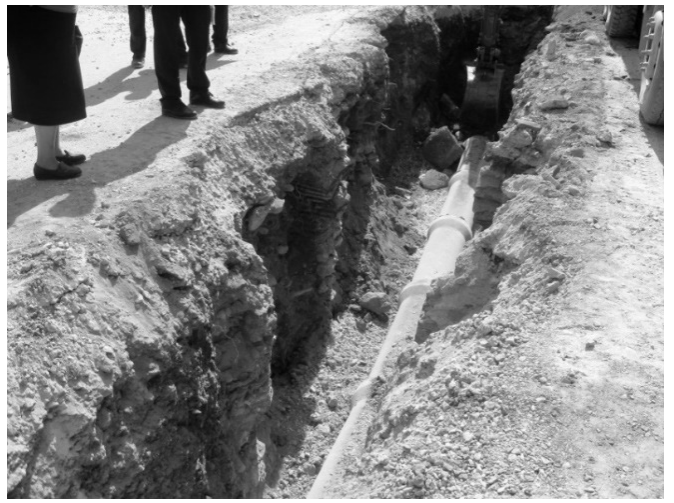

Fig. 15

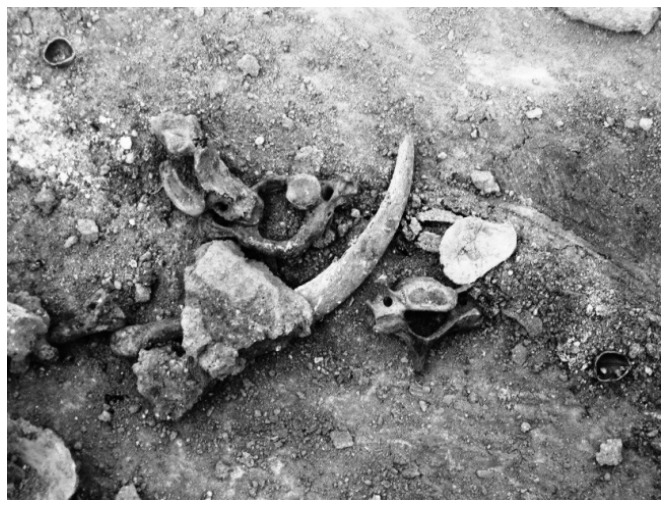

Fig. 16 


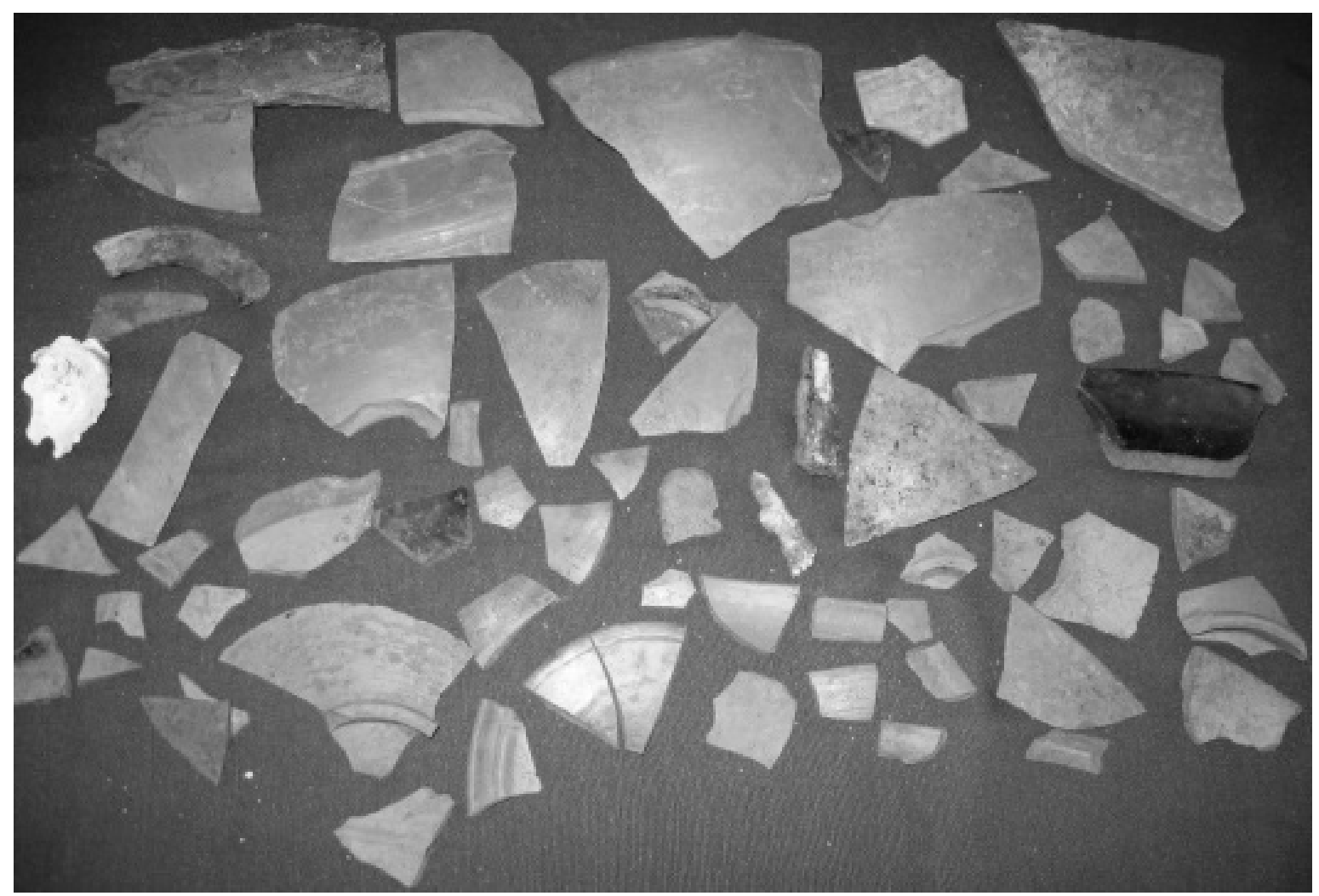

Fig. 17

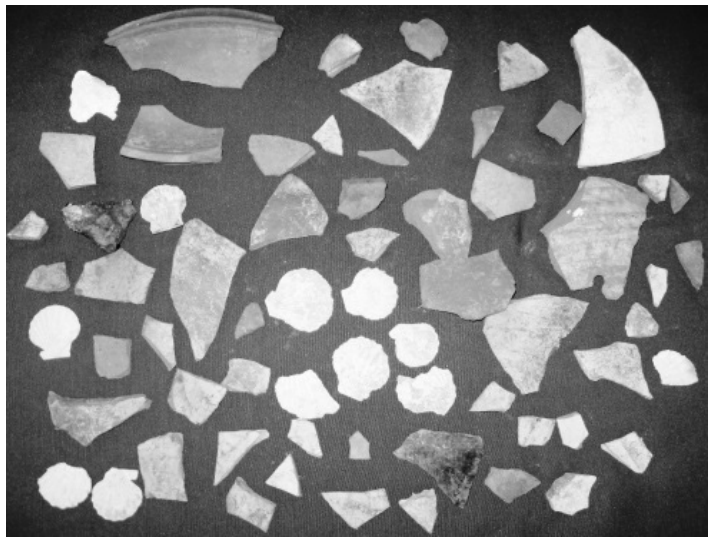

Fig. 18

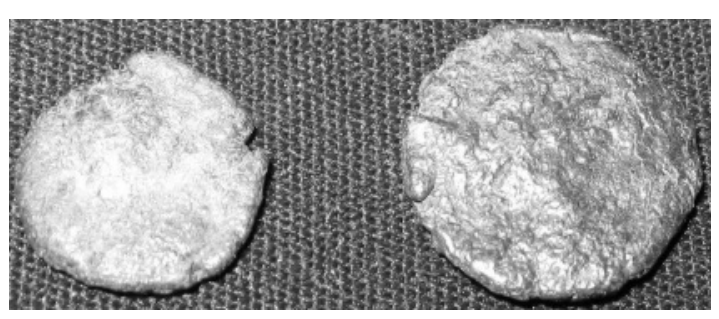

Fig. 20

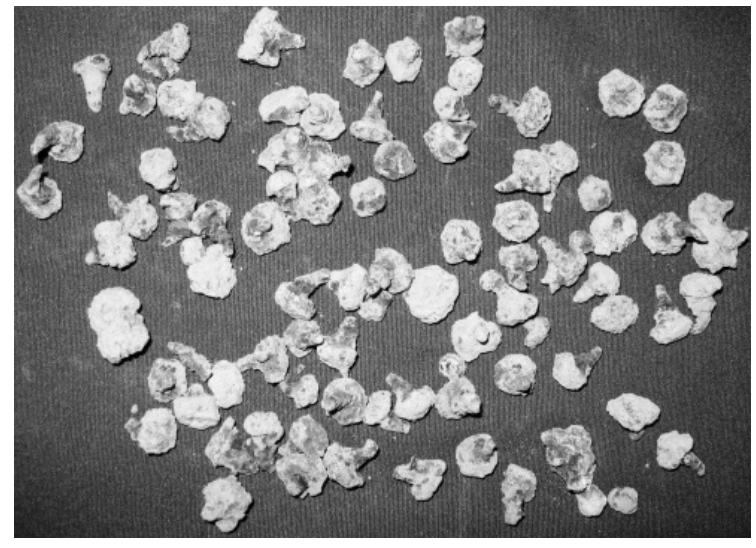

Fig. 19

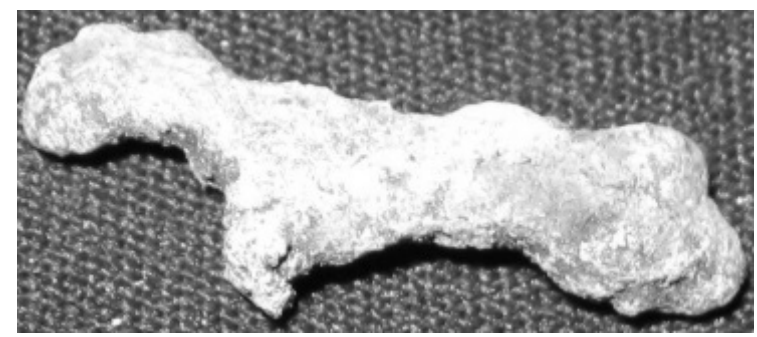

Fig. 21 